\title{
Downregulation of the $\mathrm{H}-2 \mathrm{~K}^{\mathrm{d}}$ gene by siRNA affects the cytotoxicity of murine LAK cells
}

\author{
Xin Liu, Xin Cui, Ningning Shan, Ying Li, Xiaosheng Fang, Mei Ding and Xin Wang*
}

\begin{abstract}
To investigate the effect of the $\mathrm{H}-2 \mathrm{~K}^{\mathrm{d}}$ gene on the lymphocyte membrane, we constructed a small interfering RNA (siRNA) that targets the $\mathrm{H}-2 \mathrm{~K}^{\mathrm{d}}$ gene and compared the cytotoxicity of mouse lymphokine-activated killer (LAK) cells with different $\mathrm{H}-2 \mathrm{~K}^{\mathrm{d}}$ expression states. $\mathrm{H}-2 \mathrm{~K}^{\mathrm{d}}$-targeting siRNA was transfected into spleen lymphocytes of BALB/C mice. Flow cytometry (FCM) was then performed to examine the expression of the $\mathrm{H}-2 \mathrm{~K}^{\mathrm{d}}$ gene in the transfected and control cells. Additionally, the cytotoxicity of the transfected cells toward the $\mathrm{H} 22$ and $\mathrm{K} 562$ cell lines was evaluated in vitro using the $L D H$ release assay. $\mathrm{H}-2 \mathrm{~K}^{\mathrm{d}}$-targeting siRNA significantly reduced the expression levels of the target protein, whereas pure transMessenger and non-silencing siRNA did not inhibit $\mathrm{H}-2 \mathrm{~K}^{\mathrm{d}}$ expression at the concentrations tested. The cytotoxicity of siRNA-treated LAK cells toward H22 and K562 cells was reduced significantly. The knockdown of $\mathrm{H}-2 \mathrm{~K}^{\mathrm{d}}$ gene expression by siRNA may be associated with LAK cell cytotoxicity toward neoplasm cell lines.
\end{abstract}

Keywords: RNA interference, siRNA, Posttranslational gene silencing, Lymphokine-activated killer

\section{Introduction}

Classical MHC-I molecules function both as alloantigens to trigger immune recognition and the rejection of allogeneic grafts in unmatched transplant recipients and as a platform to present self or foreign peptides that can be recognized by CD8+ T cells bearing a clonotypic $T$ cell receptor [1]. It is well known that the MHC gene expression of tumor cells is down-regulated during malignancy [2-4]. Our previous investigations showed that the expression of host MHC is also down-regulated in tumor patients [5-8]. To more precisely investigate the functional relationship between host MHC-I molecules and tumor immunity, small interfering RNA (siRNA) duplexes were transfected into spleen lymphocytes of BALB/C mice to demonstrate the effects of MHC-I.

Posttranscriptional suppression of gene expression can be achieved by the introduction of sequence-specific siRNA $[9,10]$. Using this system, we achieved simultaneous downregulation of the expression of MHC-I $\left(\mathrm{H}-2 \mathrm{~K}^{\mathrm{d}}\right)$ genes in cultured lymphokine-activated killer (LAK) cells of BALB/C mice and the inhibition of the expression of endogenous MHC-I, leading to a reduction in the cytotoxicity of murine LAK cells. This reduction in cytotoxicity might be applied

\footnotetext{
* Correspondence: xinw007@126.com

Department of Hematology, Shandong Provincial Hospital Affiliated to Shandong University, 324 Jing Wu Rd, Jinan, Shandong 250021, China
}

to determine the effect of $\mathrm{H}-2 \mathrm{~K}^{\mathrm{d}}$ on lymphocyte membranes in $\mathrm{BALB} / \mathrm{C}$ mice.

\section{Materials and methods}

\section{Cell culture}

BALB/C mice were purchased from the Animal Laboratory Center of Shandong University, Jinan, China. LAK cells were generated from spleen cells obtained from BALB/C mice by culturing the spleen cells with IL-2 $(1000 \mathrm{U} / \mathrm{ml})$ for $36 \mathrm{~h}$ in 12-well culture plates until transfection using siRNA or transMessenger. The RPMI-1640 culture medium for the cell lines and lymphocytes contained $25 \mathrm{mM}$ Hepes buffered with $44 \mathrm{mM} \mathrm{NaHCO}$ and supplemented with $10 \%$ fetal bovine serum (FBS). Cells were cultured in a humidified atmosphere containing $5 \% \mathrm{CO}_{2}$ at $37^{\circ} \mathrm{C}$. Additionally, the medium was supplemented with penicillin $(100 \mathrm{U} / \mathrm{ml})$ and streptomycin $(100 \mu \mathrm{g} / \mathrm{ml})$.

\section{Preparation and transfection of siRNA targeting the $\mathrm{H}-2 \mathrm{~K}^{\mathrm{d}}$ gene}

In this study, we prepared siRNAs targeting the mouse $\mathrm{H}-2 \mathrm{~K}^{\mathrm{d}}$ gene. siRNAs was designed according to the method described by Elbashir [9,11]. Twenty-one-nucleotide RNAs (siRNA-1) and eighteen-nucleotide RNAs (siRNA-2) were chemically synthesized by QIAGEN (Germany). The siRNAs used in this study contained 3-overhangs of 
2-deoxythymidine. The sequences of siRNA-1 pairs corresponded to nucleotides 264-282 and siRNA-2 corresponded to $427-445$ after the start codon and were as follows:

Targeted sequence: AAGAGCGATGAGCAGTGGTTC Sense strand: 5'-GAGCGAUGAGCAGUGGUUCdTdT-3' Antisense strand 3'-dTdTCUCGCUACUCGUCACC AAG-5'

Targeted sequence: GGTGATCTCTGGCTGTGAA Sense strand 5' - dTdTGGUGAUCUCUGGCUGUG-3' Antisense strand: 3'-CCACUAGAGACCGACACdTdT-5'

For the preparation of duplexes, $20 \mu \mathrm{M}$ mixed siRNAs were annealed in $1 \mathrm{ml}$ of sterile buffer $(100 \mathrm{mM}$ potassium acetate, $30 \mathrm{mM}$ HEPES-KOH, $2 \mathrm{mM}$ magnesium acetate, $\mathrm{pH}$ 7.4) for $1 \mathrm{~min}$ at $90^{\circ} \mathrm{C}$ followed by a $1 \mathrm{~h}$ incubation at $37^{\circ} \mathrm{C}$. Transfection of duplex siRNAs was performed according to the manufacturer's instructions.

Annealed siRNA-1 and siRNA-2 were transfected into spleen lymphocytes that were in good condition, and the lymphocytes were seeded $36 \mathrm{~h}$ before transfection(siRNA/ TransMessenger $1.6 \mu \mathrm{g} / 8 \mu \mathrm{l})$. Eighty-four hours after transfection, LAK cell proliferation was measured using the MTT colorimetric assay, and the effectiveness of the knockdown was assessed by flow cytometry. Cells in the non-silencing group were transfected with a non-silencing siRNA using transMessenger, and cells of the mocktransfected group were transfected with transMessenger only after culturing with IL-2 (1000 U/ml) for $36 \mathrm{~h}$.

\section{Proliferative assay}

Measurements of LAK cell proliferation were performed using the MTT (3-(4,5-dimethylthiazol-2-yl)-2,5-di-phenyltetrazolium bromide) colorimetric assay. Eighty-four hours after transfection (siRNA/TransMessenger $1.6 \mu \mathrm{g} /$ $8 \mu \mathrm{l}$, non-silencing siRNA or transMessenger only), LAK cells at $1 \times 10^{6}$ cells $/ \mathrm{ml}$ were plated in 96-well microtiter plates (Corning Costar, Cambridge, MA, USA) and incubated with $0.25 \mathrm{mg} / \mathrm{ml} \mathrm{MTT}$ for $4 \mathrm{~h}$ at $37^{\circ} \mathrm{C}$. Before the end of the assay, $100 \mu \mathrm{l}$ of DMSO was added to each well. The amount of MTT formazan product was determined by measuring the absorbance (A) using a microplate reader at a test wavelength of $570 \mathrm{~nm}$ and a reference wavelength of $655 \mathrm{~nm}$.

\section{Flow cytometry analysis of $\mathrm{H}-2 \mathrm{~K}^{\mathrm{d}}$ expression}

The analysis of surface immunofluorescence was performed using FACScan flow cytometry (Becton Dickinson, USA). LAK cells $\left(1 \times 10^{6}\right.$ cells $\left./ \mathrm{ml}\right)$ to be analyzed for immunofluorescence were incubated with a saturating amount $(10 \mu \mathrm{l})$ of FITC-labeled monoclonal anti-H-2 $\mathrm{K}^{\mathrm{d}}$ (Becton Dickinson, USA) for 30 minutes at $37^{\circ} \mathrm{C}$, washed twice in the diluent and resuspended in PBS containing $1 \%$
Table 1 Analysis of the LAK activities of the different groups $(\mathbf{n}=\mathbf{5})$

\begin{tabular}{cccc}
\hline $\begin{array}{c}\text { Experimental } \\
\text { group }\end{array}$ & $\begin{array}{c}\text { siRNA/ } \\
\text { TransMessenger }(\boldsymbol{\mu g} / \boldsymbol{\mu l})\end{array}$ & $\begin{array}{c}\text { A } \\
\text { (absorbance) }\end{array}$ & $\begin{array}{c}\text { Compared } \\
\text { with controls }\end{array}$ \\
\hline Control & $0 / 0$ & $1.46 \pm 0.14$ & \\
siRNA & $1.6 / 8$ & $1.46 \pm 0.09$ & $P>0.05$ \\
Mock-transfected & $0 / 8$ & $1.50 \pm 0.13$ & $P>0.05$ \\
Non-silencing & $1.6($ Non-si)/8 & $1.48 \pm 0.20$ & $P>0.05$ \\
\hline
\end{tabular}

formaldehyde and $0.5 \%$ sodium azide. Non-specific binding was subtracted using appropriate controls.

\section{Cytotoxicity assay}

The target cells were placed in 96-well plates at 10,000 cells/well with the appropriate number of LAK cells as indicated in $0.2 \mathrm{ml}$ of complete medium. After $4 \mathrm{~h}$ of incubation at $37^{\circ} \mathrm{C}$ in a humidified atmosphere containing $5 \% \mathrm{CO}_{2}$, the LDH assay was applied according to the manufacturer's instructions for the CytoTox $96^{\circ}$ NonRadioactive Cytotoxicity Assay. The percentage-specific release was calculated as follows:

$\%$ Cytotoxicity $=\frac{\text { Experimental }- \text { Effector Spontaneous }- \text { Target Spontaneous }}{\text { Target Maximum }- \text { Target Spontaneous }} \times 100$

Experimental counts were determined from triplicate wells.

\section{Statistical analysis}

Data are presented as the means \pm SEM. Statistical analysis was performed by one-way analysis of variance (ANOVA). All tests were performed using SPSS (version 16.0; SPSS,

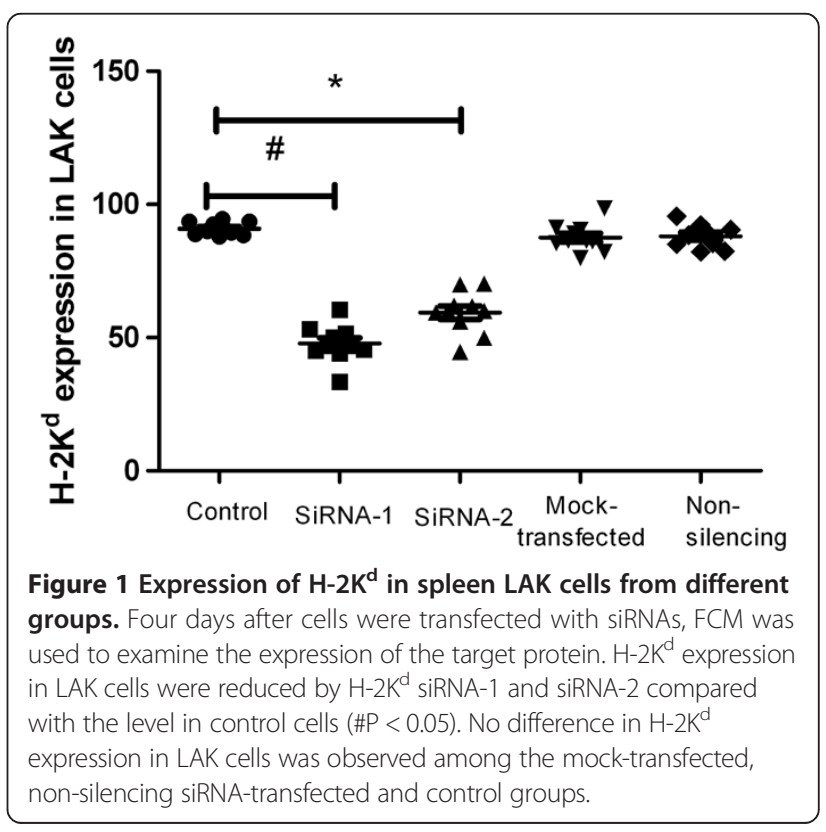


Table 2 Analysis of LAK cytotoxic activity toward H22 cells (mean \pm SEM, $n=8$ )

\begin{tabular}{ccccc}
\hline \multirow{2}{*}{ Experimental group } & \multicolumn{4}{c}{ Effector/target cell ratio } \\
\cline { 2 - 5 } & $\mathbf{1 0 : 1}$ & $\mathbf{2 0 : 1}$ & $\mathbf{3 0 : 1}$ & $\mathbf{4 0 : 1}$ \\
\hline Control & $28.6 \pm 4.1$ & $45.2 \pm 4.8$ & $68.4 \pm 5.0$ & $81.6 \pm 5.9$ \\
siRNA-1 & $27.6 \pm 2.1$ & $40.6 \pm 5.1^{*} \# \boldsymbol{\Delta}$ & $55.4 \pm 4.1^{*} \# \boldsymbol{\Delta}$ & $65.0 \pm 2.1^{*} \# \boldsymbol{\Lambda}$ \\
Mock-transfected & $26.9 \pm 5.6$ & $46.9 \pm 5.7$ & $70.3 \pm 6.0$ & $80.5 \pm 4.6$ \\
Non-silencing & $30.3 \pm 3.9$ & $44.3 \pm 3.8$ & $67.0 \pm 4.9$ & $82.0 \pm 2.6$ \\
\hline
\end{tabular}

${ }^{*} P<0.01$, siRNA-transfected group compared with the control group;

${ }^{\#} P<0.01$, siRNA-transfected group compared with the mock-transfected group;

$\Delta P<0.01$, siRNA-transfected group compared with the non-silencing group.

Inc., Chicago, IL, USA), and the level of significance was set at a $P$ value less than 0.01 .

\section{Results}

siRNA has no toxic effect on spleen LAK cells

No cell morphology abnormalities or cell breakage was observed in any group using an inverted microscope. Table 1 shows that the siRNA and transMessenger had no inhibitory effect on the proliferation of LAK cells.

\section{$\mathrm{H}-2 \mathrm{~K}^{\mathrm{d}}$ Expression in spleen LAK cells}

FCM was used to examine the targeted protein expression. Eighty-four hours after transfection, $\mathrm{H}-2 \mathrm{~K}^{\mathrm{d}}$ expression in LAK cells was reduced by $\mathrm{H}-2 \mathrm{~K}^{\mathrm{d}}$ siRNA-1 $(47.8 \pm 6.9 \%)$ and $(59.5 \pm 7.9 \%)$ by $\mathrm{H}-2 \mathrm{~K}^{\mathrm{d}}$ siRNA- 2 compared with the levels in mock-transfected cells $(87.7 \pm 5.1 \% ; P<0.01)$, nonsilencing siRNA-transfected cells $(88.2 \pm 4.3 \% ; P<0.01)$ and control cells $(90.9 \pm 2.4 \% ; P<0.01)$. No significant difference in $\mathrm{H}-2 \mathrm{~K}^{\mathrm{d}}$ expression in LAK cells was found among the mock-transfected, non-silencing siRNA-transfected and control groups $(P>0.05)$ (Figure 1$)$.

\section{Calculation of LAK cell cytotoxicities}

After induction with IL-2 for 5 days, LAK cells from BALB/C mice showed marked cytotoxicity toward $\mathrm{H} 22$ and K562 cells. The addition of siRNA-1-treated LAK cells resulted in a cytotoxicity decrease of $20.3 \%$ ( $\mathrm{P}<0.05$; effector/target cell ratio: 40:1; Table 2) toward H22 cells. Similar results were obtained in cultures of K562 cells, in which siRNA-treated LAK cells (effector/target cell ratio: 40:1) exhibited a decreased in cytotoxicity from $(76.8 \pm 5.8)$ to $(49.6 \pm 7.7)(\mathrm{P}<0.05$; Table 3$)$. However, no significant difference was found among the mock-transfected, non-silencing siRNA-transfected and control groups in the present study.

\section{Discussion}

The major histocompatibility complex (MHC) $\mathrm{H}-2 \mathrm{~K}^{\mathrm{d}}$, as the MHC-I molecule of BALB/c mice, is a cell surface glycoprotein that plays critical roles in the regulation of tumor immune responses. These molecules are expressed on the surface of all nucleated cells and are necessary for the presentation of peptide antigens to cytotoxic $\mathrm{T}$ lymphocytes (CTLs) [12,13] and for the immune regulatory activity exerted by NK cells $[14,15]$. It is widely accepted that the total or partial loss of MHC class I molecules on tumor cells is one of the main mechanisms of tumor escape. However, the effects of MHC on peripheral blood mononuclear cells (PBMCs) remain unclear. In the present study, we first evaluated the cytotoxicity of LAK cells toward tumor cells with different expression states of MHC-I. Down-regulated MHC-I expression in LAK cells led to lower cytotoxicity toward H22 cells and K562 cells.

Studies have shown that the high-density expression of MHC class I molecules can protect $\mathrm{T}$ cells from deletion mediated by antibodies and macrophages [16]. When the expression of these MHC class I molecules is masked, this resistance collapses, indicating that highly expressed MHC class I molecules can prolong the survival time of $\mathrm{T}$ cells. Many experiments have also been designed to evaluate the

Table 3 Analysis of LAK cytotoxic activity toward K562 cells (mean \pm SEM, $n=8$ )

\begin{tabular}{ccccc}
\hline \multirow{2}{*}{ Experimental group } & \multicolumn{4}{c}{ Effector/target cell ratio } \\
\cline { 2 - 5 } & $\mathbf{1 0 : 1}$ & $\mathbf{2 0 : 1}$ & $\mathbf{3 0 : 1}$ & $\mathbf{4 0 : 1}$ \\
\hline Control & $30.1 \pm 9.8$ & $50.1 \pm 6.4$ & $63.4 \pm 7.6$ & $76.8 \pm 5.8$ \\
siRNA-1 & $28.4 \pm 36.9^{*} \# \boldsymbol{\Lambda}$ & $31.3 \pm 6.5^{*} \# \boldsymbol{\Delta}$ & $36.9 \pm 5.9^{*} \# \boldsymbol{\Delta}$ & $49.6 \pm 7.7^{*} \# \boldsymbol{\Delta}$ \\
Mock-transfected & $28.9 \pm 6.7$ & $49.9 \pm 5.8$ & $66.3 \pm 8.0$ & $74.9 \pm 8.1$ \\
Non-silencing & $31.4 \pm 8.7$ & $51.2 \pm 9.1$ & $64.9 \pm 8.9$ & $80.0 \pm 9.7$ \\
\hline
\end{tabular}

${ }^{*} P<0.01$, siRNA-1-transfected group compared with the control group;

${ }^{\#} P<0.01$, siRNA-1-transfected group compared with the mock-transfected group;

$\Delta P<0.01$, siRNA-1-transfected group compared with the non-silencing group. 
significance of host MHC antigens [17-19]. Lemorvan [20] discovered that the expression of PBMCs HLA-B mRNA is reduced as one advances into old age, when one's immune system is also weakened. Studies on varicella zoster virus (VZV) pathogenesis have demonstrated that cell surface MHC I expression is downregulated specifically in VZVinfected human $\mathrm{CD}^{+} \mathrm{T}$ lymphocytes [21,22]. siRNA was then applied to spleen LAK cells from BALB/C mice to assess the effects of MHC-I.

LAK cells are lymphocytes exposed to interleukin-2 for 4 to 6 days. Several studies have shown that the cellular population mediating LAK cell activity consists largely of IL-2-stimulated CTLs and NK cells. Specific surface markers have not been found on LAK cells $[23,24]$. The molecular mechanisms involved in the recognition of tumor cells by CTLs and NK cells have been partially elucidated in recent years. MHC class I-bearing cells interact with the T-cell receptor (TCR) on CD8+ CTL cells, triggering a cascade of $\mathrm{T}$-signal events that ultimately lead to cell proliferation, cytokine production and target cell lysis [25-27]. This positive effect is associated with the expression of self-MHC-I-specific receptors on CTL and NK cells that were originally identified as inhibitory receptors in effector responses [28]. Several investigators have invoked a role for abnormally low expression of MHC class I molecules on tumors in the recognition process by correlating MHC-I expression with NK insensitivity utilizing IFN treatment, which increases MHC-I expression, or selection of cell clones with varying levels of MHC-I expression [29]. However, experiments utilizing transfection of MHC class I genes into sensitive cell lines have yielded conflicting results [30], indicating that MHC-I expression is not the sole recognition mechanism. The down-regulation of MHC-I antigens in NK and lymphocytes may provide an important mechanism in the tumor immune response. Large numbers of lymphocytes exist in the spleen in vivo; however, their slow proliferation prevents them from being cultured in vitro. Induced by IL-2, spleen lymphocytes signal to LAK cells, which can lyse not only self tumor cells but also isotype entity tumor cells [31,32]. Our study demonstrated that the inhibition of $\mathrm{H}-2 \mathrm{~K}^{\mathrm{d}}$ expression in mice reduced the cytotoxicity of LAK cells toward H22 and K562 target cells, suggesting that there is a direct correlation between $\mathrm{H}-2 \mathrm{Kd}$ expression and the cytotoxicity of CTLs and NK cells.

Our study strongly suggests that the resistance to tumors is influenced by MHC-I expression in the host as well as in the target cells. The expression of MHC molecules on the tumor cell surface is a feature of tumor cells, whereas the change in host MHC expression reflects the state of $\mathrm{MHC}$ in the whole body and represents the host's immune nature. The expression of MHC-I molecules on host peripheral blood lymphocytes reflect their immune competence as an anti-viral and anti-tumor molecules. A decrease in host MHC-I expression, leading to the unresponsiveness of CTLs and NK cells due to the default of antigen presentation, may play an important role in tumor development. Measuring MHC-I expression will contribute to our understanding of host immune status and provide new insights into tumor immunity.

\section{Competing interests}

The authors declared that they have no competing interests.

\section{Authors' contributions}

LX participated in experimental design and manuscript writing; CX contributed to data analysis; SN and LY contributed to experimental design and the statistical analysis; FXS and DM contributed to data analysis; WX contributed to experimental design and writing of the manuscript. All authors revised the manuscript critically and approved the final version to be published.

\section{Acknowledgements}

This study was partially supported by research funding from the National Science Foundation of China (No. 81100334), Natural Science Foundation of Shandong Province (ZR2009CM001, ZR2010HQ002, Y2007C059). The funders had no role in study design, data collection and analysis, decision to publish, or preparation of the manuscript.

Received: 6 March 2013 Accepted: 4 November 2013 Published: 9 November 2013

\section{References}

1. Adams EJ, Parham P: Genomic analysis of common chimpanzee major histocompatibility complex class I genes. Immunogenetics 2001, 53:200-208.

2. Lorenzi S, Forloni M, Cifaldi L, Antonucci C, Citti A, Boldrini R, et al: IRF1 and NF-kB Restore MHC Class I-Restricted Tumor Antigen Processing and Presentation to Cytotoxic T Cells in Aggressive Neuroblastoma. PLoS One 2012, 7:e46928.

3. Del Toro-Arreola S, Arreygue-Garcia N, Aguilar-Lemarroy A, Cid-Arregui A, Jimenez-Perez M, Haramati J, et al: MHC class I-related chain A and B ligands are differentially expressed in human cervical cancer cell lines. Cancer Cell Int 2011, 11:11-15.

4. Kudinov Y, Wiseman CL, Kharazi Al: Phorbol myristate acetate and Bryostatin 1 rescue IFN-gamma inducibility of MHC class II molecules in LS1034 colorectal carcinoma cell line. Cancer Cell Int 2003, 3:4.

5. Zhang ZM, Li YJ, Guan X, Yang XY, Gao XM, Yang XJ, et al: Down-regulation of human leukocyte antigens class I on peripheral T lymphocytes and NK cells from subjects in region of high-incidence gastrointestinal tumor. Chin Med J (Engl) 2011, 124:1813-1817.

6. Wang RF, Zeng G, Johnston SF, Voo K, Ying H: T cell-mediated immune responses in melanoma: implications for immunotherapy. Crit Rev Oncol Hematol 2002, 43:1-11.

7. Wang CX, Wang JF, Liu M, Zou X, Yu XP, Yang XJ, et al: Expression of HLA class I and II on peripheral blood lymphocytes in HBV infection. Chin Med J (Engl) 2006, 119:753-756.

8. Yang XJ, Zou X, Wang CX, Zhang Y, Wang LS, Wang CX, et al: The ralationship between peripheral blood lymphocytesinfected by HBV and expressionof HLA class I antigenin. J Nat Med 2002, 82:1450-1499.

9. Elbashir SM, Harborth J, Lendeckel W, Yalcin A, Weber K, Tuschl T: Duplexes of 21-nucleotides RNAs mediated RNA interference in cultured mammalian cells. Nature 2001, 411:494-498.

10. Song TF, Zhang ZF, Liu L, Yang T, Jiang J, Li P: Small interfering RNA-mediated silencing of heat shock protein 27 (HSP27) Increases chemosensitivity to paclitaxel by increasing production of reactive oxygen species in human ovarian cancer cells (HO8910). J Int Med Res 2009, 37:1375-1388.

11. Elbashir SM, Harborth J, Weber K, Tuschl T: Analysis of gene function in somatic mammalian cells using small interfering RNAs. Methods 2002, 26:199-213.

12. Townsend AR, Rothbard J, Gotch FM, Bahadur G, Wraith D, McMichael AJ: The epitopes of influenza nucleoprotein recognized by cytotoxic $T$ lymphocytes can be defined with short synthetic peptides. Cell 1986, 44:959-968. 
13. Boon T, Cerottini JC, Van den Eynde B, van der Bruggen P, Van Pel A: Tumor antigens recognized by T lymphocytes. Annu Rev Immunol 1994, 12:337-365

14. Ljunggren $\mathrm{HG}$, Karre K: In search of the 'missing self': $\mathrm{MHC}$ and NK cell recognition. Immunol Today 1990, 11:237-244

15. Trowsdale J: Genetic and functional relationships between MHC and NK receptor genes. Immunity 2001, 15:363-374.

16. Orlikowsky T, Wang Z, Dudhane A, Mittler R, Trejo V, Dannecker GE, et al: Elevated major histocompatibility complex class I expression protects $T$ cells from antibodyand macrophage-mediated deletion. Immunology 1998, 95:437-442.

17. Collins RW: Human MHC, class I chain related (MIC) genes: their biological function and relevance to disease and transplantation. Eur J Immunogenet 2004, 13:105-114.

18. Wedekind C, Walker M, Little TJ: The separate and combined effects of MHC genotype, parasite clone, and host gender on the course of malaria in mice. BMC Genet 2006, 7:55.

19. Wu JD, Atteridge $C L$, Wang $X$, Seya T, Plymate SR: Obstructing shedding of the immunostimulatory MHC class I chain-related gene B prevents tumor formation. Clin Cancer Res 2009, 5:632-640.

20. Le Morvan C, Cogne M, Troutaud D: HLA-A and HLA-B transcripition decrease with aging in peripheral blood lymphocytes. J Clin Exp Immunol 2001, 125:245-250.

21. Abendroth A, Arvin A: Varicella-zoster virus immune evasion. Immunol Rev 1999, 168:143-156.

22. Morrow G, Slobedman B, Cunningham AL, Abendroth A: Varicella-zoster virus productively infects mature dendritic cells and alters their immune function. J Virol 2003, 77:4950-4959.

23. Thomas H, Sikora K: Biological approaches to cancer therapy. J Int Med Res 1989, 17:191-204.

24. Phillips JH, Lanier LL: Dissection of the lymphokine activated killer phenomenon: relative contribution of peripheral blood natural killer cells and T lymphocytes to cytolysis. J Exp Med 1986, 164:814.

25. Johnsen AK, Templeton DJ, Sy M, Harding CV: Deficiency of transporter for antigen presentation (TAP) in tumor cells allows evasion of immune surveillance and increases tumorigenesis. J Immunol 1999, 163:4224-4231.

26. Seliger B, Maeurer MJ, Ferrone S: Antigen-processing machinery breakdown and tumor growth. Immunol Today 2000, 21:455-464.

27. Ma Y, Xu YC, Tang L, Zhang Z, Wang J, Wang HX: Cytokine-induced killer (CIK) cell therapy for patients with hepatocellular carcinoma: efficacy and safety. Exp Hematol Oncol 2012, 1:11.

28. Sungjin K, Jennifer PL, StevenTruscott M, Truscott, Song YJ, et al: Licensing of natural killer cells by host major histocompatibility complex class I molecules. Nature 2005, 436:709-713.

29. Storkus WJ, Howell DN, Salter RD, Dawson JR, Cresswell P: NK susceptibility varies inversely with target cell class I HLA antigen expression. J Immunol 1987, 138:1657.

30. Maio M, Altomonte M, Tatake R, Zeff A, Ferrone S: Reduction in susceptibility to natural killer cell-mediated lysis of human FO-1 melanoma cell after induction of HLA Class I antigen expression by transfection with B2m gene. J Clin Invest 1991, 88:282.

31. Rosenberg SA, Lotze MT, Muul LM, Chang AE, Avis FP, Leitman S, et al: A progress Handreport on the treatment of 157 patients with advanced cancer using lymphokine-activated killer cells and interleukin-2 or high dose interleukin-2 alone. N Engl J Med 1987, 316:889.

32. West WH, Tauer KW, Yannelli GD, Marshall GD, Orr DW, Thurman GB, et al: Constantinfusion recombinant interleukin-2 in adoptive immunotherapy of advanced cancer. N Engl J Med 1987, 316:898.

doi:10.1186/1475-2867-13-112

Cite this article as: Liu et al:: Downregulation of the $\mathrm{H}-2 \mathrm{~K}^{\mathrm{d}}$ gene by siRNA affects the cytotoxicity of murine LAK cells. Cancer Cell International 2013 13:112.

\section{Submit your next manuscript to BioMed Central and take full advantage of:}

- Convenient online submission

- Thorough peer review

- No space constraints or color figure charges

- Immediate publication on acceptance

- Inclusion in PubMed, CAS, Scopus and Google Scholar

- Research which is freely available for redistribution

Submit your manuscript at www.biomedcentral.com/submit
C Biomed Central 